\title{
Larvicidal effects of a neem (Azadirachta indica) oil formulation on the malaria vector Anopheles gambiae Fredros O Okumu ${ }^{1,2}$, Bart GJ Knols ${ }^{3}$ and Ulrike Fillinger*4
}

Address: ${ }^{1}$ University of Nairobi, School of Biological Sciences, P.O. Box 3019700100 GPO Nairobi Kenya, ${ }^{2}$ Ifakara Health Research and Development Centre, Public Health Entomology Unit, P.O. Box 53 Kilombero Tanzania, ${ }^{3}$ Laboratory of Entomology, Wageningen University and Research Centre, P.O. Box 8031, 6700 EH, Wageningen, The Netherlands and ${ }^{4}$ Durham University, School of Biological and Biomedical Sciences, South Road, Durham, DH1 3LE, UK

Email: Fredros O Okumu - fros2001@hotmail.com; Bart GJ Knols - bart.knols@wur.nl; Ulrike Fillinger* - ulrike.fillinger@durham.ac.uk

* Corresponding author

Published: 22 May 2007

Malaria Journal 2007, 6:63 doi:10.1 I86/1475-2875-6-63

This article is available from: http://www.malariajournal.com/content/6/I/63

(C) 2007 Okumu et al; licensee BioMed Central Ltd.

This is an Open Access article distributed under the terms of the Creative Commons Attribution License (http://creativecommons.org/licenses/by/2.0), which permits unrestricted use, distribution, and reproduction in any medium, provided the original work is properly cited.
Received: 24 January 2007

Accepted: 22 May 2007

\begin{abstract}
Background: Larviciding is a key strategy used in many vector control programmes around the world. Costs could be reduced if larvicides could be manufactured locally. The potential of natural products as larvicides against the main African malaria vector, Anopheles gambiae s.s was evaluated.

Methods: To assess the larvicidal efficacy of a neem (Azadirachta indica) oil formulation (azadirachtin content of $0.03 \% \mathrm{w} / \mathrm{v}$ ) on An. gambiae s.s., larvae were exposed as third and fourth instars to a normal diet supplemented with the neem oil formulations in different concentrations. A control group of larvae was exposed to a corn oil formulation in similar concentrations.

Results: Neem oil had an $\mathrm{LC}_{50}$ value of II ppm after 8 days, which was nearly five times more toxic than the corn oil formulation. Adult emergence was inhibited by $50 \%$ at a concentration of $6 \mathrm{ppm}$. Significant reductions on growth indices and pupation, besides prolonged larval periods, were observed at neem oil concentrations above $8 \mathrm{ppm}$. The corn oil formulation, in contrast, produced no growth disruption within the tested range of concentrations.

Conclusion: Neem oil has good larvicidal properties for An. gambiae s.s. and suppresses successful adult emergence at very low concentrations. Considering the wide distribution and availability of this tree and its products along the East African coast, this may prove a readily available and cheap alternative to conventional larvicides.
\end{abstract}

\section{Background}

Malaria in sub-Saharan Africa can be controlled by attacking its prime vectors, notably Anopheles gambiae s.l. Since the onset of mosquito control activities in the early 1900s, several challenges continue to hinder efforts to effectively control malaria. These include insecticide resistance, limited access to essential resources (human, capital, and equipment) that affect conventional use of control methods, and insect adaptation and altered behavioural traits, such as exophily and exophagy [1]. The need to develop and incorporate new alternative tools for integrated vector management remains key, where methods to reduce adult biting and control of aquatic stages are used in combination. Use of larvicides, which dates back to as early as 1899, when Ronald Ross applied kerosene on anopheline larval breeding sites in Sierra Leone [2], is an approach with great potential for future malaria vector control [3]. It is worth emphasizing that although larval control is not 
widely used in the tropics today, in the past the greatest achievements in malaria control were based on the use of larvicides, for example the eradication of An. gambiae from Brasil [4] and Anopheles arabiensis from Egypt [5].

At present, mosquito larvicides include organophosphates, insect growth regulators and microbial larvicides. Current research focuses on microbials such as Bacillus thuringiensis var. israelensis (Bti) and Bacillus sphaericus $[6,7]$ as well as on botanicals with larvicidal, oviposition inhibiting, repellent or insect growth regulatory effects $[8,9]$. Such products contain a multitude of active ingredients with different modes of action, which lessens the chance of resistance developing in mosquito populations. The neem plant (Azadirachta indica) and its derived products have shown a variety of insecticidal properties on a broad range of insect species [10,11].

Neem products have been shown to exhibit a wide range of effects that are potentially useful for malaria control and include antifeedancy [9], ovicidal activity, fecundity suppression [12], insect growth regulation $[13,14]$ and repellency [15-17]. These effects are frequently attributed to the azadirachtin contents of the products $[10,13]$. Recent studies have also demonstrated neem-induced effects on vitellogenesis and severe degeneration of follicle cells during oogenesis in mosquitoes [9]. It has been argued that the pesticidal efficacy, environmental safety, and public acceptability of neem and its products for control of crop pests would ensure its adoption into mosquito control programmes $[12,18]$. Presently, however, none of the commercially available neem formulations, which include emulsifiable concentrates (ECs), wettable products (WPs), suspension concentrates, ultra low volume (ULV) and granular formulations, are used for this purpose.

Neem-based products are relatively safe towards non-target biota, with only minimal risk of direct adverse effects on aquatic macro invertebrates resulting from contamination of water bodies with neem-based insecticides [1921]. In addition, the products are less likely to induce resistance due to their multiple modes of action on insects [22]. Research on neem products for the control of arthropods of medical and veterinary importance has been ongoing for some time. Various studies have focused on the culicine species Culex tarsalis and Culex quinquefaciatus $[12,18,22,23]$, besides Aedes aegypti [24-26]. There have also been studies that assessed the larvicidal potential of neem products on anophelines, notably Anopheles culicifacies, An. arabiensis, An. gambiae and Anopheles stephensi. $[9,22,27,28]$. The current studies aimed to determine the larvicidal potency of an emulsified neem oil formulation (32\% neem oil) against An. gambiae s.s., which is one of the most notorious malaria vectors in sub-Saharan Africa.

\section{Materials and methods Mosquitoes}

The An. gambiae s.s. larvae used in this study were from a colony established in 2001 at the Thomas Odhiambo campus of the International Centre of Insect Physiology and Ecology (ICIPE), Mbita Point, western Kenya. Mosquitoes were reared under semi-natural conditions in a greenhouse, following standard operating procedures for mosquito maintenance [29-31].

\section{Oil formulations}

Two experimental formulations, both of which were emulsified concentrates, were tested and compared. The test formulation was an emulsified concentrate, containing 32\% neem seed oil (an equivalent of $0.03 \%$ azadirachtin), an emulsifier (5\%) and 63\% isopropanol (solvent). The neem oil was extracted from seeds collected in coastal Kenya. A corn oil formulation with similar solvent and emulsifier contents and proportions was used as the control formulation.

\section{Experimental procedures}

The larvicidal effects of the neem oil formulation were tested on An. gambiae s.s. under greenhouse conditions [32]. Baseline tests were initially run in distilled water to determine the range of lethal doses of the formulation [33]. The maximum dosage of the neem formulation to be applied was determined as $32 \mathrm{ppm}$, as this resulted in high larval mortality within days. In the main experiment, the larvae were reared in $15 \times 20 \mathrm{~cm}$ plastic trays. Stock solutions of $1,000 \mathrm{ppm}(0.1 \%)$ of the two experimental formulations were prepared. Six aliquots were prepared from this stock solution to obtain concentrations of 0.5 , $2,4,8,16$ and $32 \mathrm{ppm}$ respectively. A fresh stock solution was prepared for each replicate experiment. X ppm in this case refers to $\mathrm{X}$ parts of the experimental formulation mixed with $(1.000 .000-\mathrm{X})$ parts of the ordinary larval breeding medium. Thus each of the six trays had the ordinary larval rearing medium supplemented with the neem formulation at the different concentrations (i.e. 0.5 to 32 $\mathrm{ppm})$. The same method of application was used for the corn oil formulation. Fifty $3^{\text {rd }}$ to $4^{\text {th }}$ instar larvae were introduced carefully into each tray which were then topped up to $1 \mathrm{~L}$. A negative control was run in freshly collected water from Lake Victoria, routinely used to rear larvae of the colony.

The larvae in all the trays were fed every $24 \mathrm{hrs}$ on equal amounts of Tetramin ${ }^{\circledast}$ Baby fish food using a 'dip stick' (approx. $0.015 \mathrm{~g}$ ). Tetramin ${ }^{\circledR}$ Baby is a powdered diet and spreads evenly across the water surface. Six replicates were run under the same microclimatic conditions. The mortality of the larvae was monitored every $24 \mathrm{hrs}$. All the pupae were collected, counted and kept in labeled glass vials capped with cotton wool. The solution with which the 
pupae were collected was also kept in the same vials such that the pupae remained under the same experimental conditions and concentrations as during the larval stages. The pupae were further monitored for 24 to 48 hours when emerging adults were counted and recorded. Larvae were observed during their entire lifespan, in order to monitor the usually delayed effects of neem products $[34,35]$.

Percentage cumulative pupation and the mean larval periods were calculated for all concentrations of both the corn oil and neem oil formulation. The mean larval periods for each tray were determined using the following formula:

$$
\begin{gathered}
\left(\left(\mathrm{A}^{*} 1\right)+\left(\mathrm{B}^{*} 2\right)+\left(\mathrm{C}^{*} 3\right)+\left(\mathrm{D}^{*} 4\right) \ldots \ldots \ldots+\left(\mathrm{H}^{*} 8\right)\right) / \text { total } \\
\text { number of pupae collected }
\end{gathered}
$$

where A, B, C, D...... H are the number of pupae that were collected on days $1,2,3,4$ to 8 respectively. The logical argument in this formula is that the larvae which pupated after a particular number of days had actually lived that same number of days. The larval period is summed across the third and fourth larval instars. Growth indices of the larvae were determined as the ratio between percent pupation and the mean larval periods [23].

Percentage emergence inhibition was determined as 100A where A was the \% successful emergence. Emerging adults were grouped age-wise whenever they emerged, and kept in different cages. Adults emerging from each experimental tray were kept separately. This set up was used to study the sublethal effects of the treatments that might have been carried over from the aquatic stage treatments. Adult mosquitoes were continuously provided with water and a $6 \%$ glucose solution dispensed from clean cotton wool daily. These mosquitoes were kept at room temperature and a photoperiod of $12 \mathrm{hrs} \mathrm{light/dark.}$ No further neem oil or corn oil treatments were administered in this phase of the experiment. Adult mortality was recorded every 24 hrs. The mean longevity of these adults was calculated for both sexes and oil formulations at the different concentrations. Longevity was calculated as the total number of days lived by a single adult mosquito from emergence to death. Adults emerging from the negative control trays (no oil) were used as the control group. The maximum number of days lived by the emerged adults from each group was also recorded.

\section{Statistical analysis}

The mortality of the larvae (300 per concentration) in both the neem and corn oil formulation were corrected using Abbott's formula [36], each with the data gained from the negative control. Log-probit analysis [37] was used to determine the median $\left(\mathrm{LC}_{50}\right)$ and $90 \%$ lethal concentration $\left(\mathrm{LC}_{90}\right)$. Emergence inhibition (EI) as caused by the two formulations was also corrected with Abbott's formula [36] and the $\mathrm{EI}_{50}$ and $\mathrm{EI}_{90}$ values determined using probit analyses. The aquatic developmental parameters; growth indices, larval periods and pupation were compared, for both the oil formulations and the negative control, by Analysis of Variance (ANOVA) using Tukey's studentized range test (honestly significant difference test). The longevity of the emergent adults was compared by student t-tests. SAS software was used for the analyses.

\section{Results}

Neem oil was highly larvicidal at high concentrations (32 ppm), but this activity declined progressively as the dose decreased (Figure 1). Corn oil had little if any larvicidal properties at any concentration tested. At concentrations above $16 \mathrm{ppm}$ of the neem oil formulation, over $80 \%$ of the observed mortality occurred within the first 72 hrs, while at lower concentrations the rate of mortality was very slow and some larvae, in spite of being $3^{\text {rd }}$ or $4^{\text {th }}$ instar, lived as long as 8 days before they either pupated or died. The median anti-larval potency $\left(\mathrm{LC}_{50}\right)$ of the neem oil formulation after 8 days was $10.7 \mathrm{ppm}$, and the $\mathrm{LC}_{90}$ was $24.1 \mathrm{ppm}$ (Table 1). This was 4.7 times lower than the corn oil formulation, which showed an $\mathrm{LC}_{50}$ of $50.7 \mathrm{ppm}$. The concentration of neem oil that induced median emergence inhibition $\left(\mathrm{EI}_{50}\right)$ was $6.4 \mathrm{ppm}$ while the $\mathrm{EI}_{90}$ was $17.4 \mathrm{ppm}$. Table 1 shows that the $\mathrm{EI}_{50}$ value of the neem oil formulation was approximately 8 times lower than that of the corn oil formulation. At $32 \mathrm{ppm}$ the neem formulation inhibited $99.3 \%$ of emergence. Whereas the adult emergence steadily increased with decreasing concentrations of the neem oil formulation, there were no observable increments with the corn oil formulation (Figure 1).

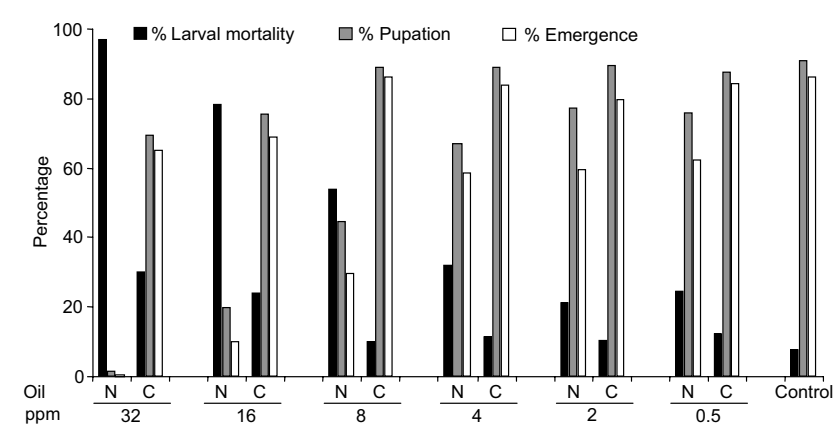

Figure I

Percentage larval mortality, pupation and adult emergence (as proportion of original numbers tested) of $3^{\text {rd }}-4^{\text {th }}$ instar larvae of An. gambiae following exposure to various concentrations (0.5-32 ppm) of neem oil $(\mathrm{N})$ or corn oil (C). Adult emergence values are percentages of the total number of mosquitoes tested as larvae. 
Table I: Larval mortality and emergence inhibition of An. gambiae s.s. after exposure to neem oil and corn oil formulations.

\begin{tabular}{|c|c|c|c|c|c|c|}
\hline \multirow[b]{3}{*}{ Oil } & \multicolumn{4}{|c|}{ Larval mortality $\dagger$} & \multicolumn{2}{|c|}{ Emergence inhibition } \\
\hline & \multicolumn{2}{|c|}{$192 \ddagger$} & \multicolumn{2}{|c|}{72} & \multirow[b]{2}{*}{$\mathrm{El}_{50}$} & \multirow[b]{2}{*}{$\mathrm{El}_{90}$} \\
\hline & $\mathrm{LC}_{50}$ & $\mathrm{LC}_{90}$ & $\mathrm{LC}_{50}$ & $\mathrm{LC}_{90}$ & & \\
\hline Neem & $10.7(7.55-12.15)$ & $24.12(12.37-37.68)$ & $22.11(17.14-31.42)$ & $109.34(65.48-256.20)$ & 6.44 (5.01-7.99) & 17.38 (14.62-21.91) \\
\hline Corn & $50.6(37.96-88.69)$ & $86.85(62.29-133.67)$ & $58.24(42.24-121.66)$ & 91.79 (63.54-208.38) & 47.28 (|4.40-9|.27) & $79.75(16.65-135.36)$ \\
\hline
\end{tabular}

† All concentrations in parts per million (ppm) with $95 \%$ confidence intervals between brackets; $\ddagger$ Hours after exposure. Six concentrations were tested and replicated with 50 mosquitoes six times each $(n=300)$. LC and El values were determined by probit analysis (Finney 197I). Mortality was corrected using Abbott's formula (Abbott 1925) with values obtained from the negative control.

Table 2 shows the impacts of the two oil formulations on the aquatic growth and development of An. gambiae s.s.. Growth indices of the larvae were significantly reduced by neem oil formulation treatments above $8 \mathrm{ppm}(\mathrm{P}<0.05)$. Addition of this formulation to the diet of the larvae reduced their growth indices from 25.8 (in lake water based medium) to as low as 0.5 and 3.6 when applied at concentrations of $32 \mathrm{ppm}$ and $16 \mathrm{ppm} ; 96 \%$ and $86 \%$ reductions respectively. The tests also showed that larval development times were significantly prolonged at concentrations equal to or higher than $16 \mathrm{ppm}$ of the neem oil formulation. In addition, pupation was significantly inhibited at concentrations higher than $8 \mathrm{ppm}(\mathrm{P}<0.05)$. When compared with the negative control, the corn oil formulation did not have any significant impacts on either the larval periods, pupation or growth indices of the mosquitoes tested $(\mathrm{P}<0.05)$. Table 3 shows the sub-lethal impacts of the two oil formulations on the emergent adult mosquitoes. When mosquito larvae were exposed to neem treatments in their diet until they pupated and subsequently emerged, sublethal effects on the emergent adults were observed.

The longevity of both male and female adult An. gambiae s.s. whose larvae and pupae had been reared in a diet enriched with the neem oil formulation was significantly lower than the longevity of the adults whose larvae and pupae had been reared in the corn oil enriched diet $(\mathrm{P}<$ 0.001). At all the tested concentrations, the maximum number of days lived by the emergent adults was significantly higher after the corn oil formulation treatments than after the neem oil formulation treatment $(\mathrm{P}<0.001)$. Generally the adults emerging from neem oil formulation treated trays had a shorter life span than emergent adults from either corn oil formulation treated or the untreated trays. There were no observable sub-lethal effects of the corn oil formulation.

\section{Discussion}

Neem oil was an effective larvicide against An. gambiae larvae; it was highly toxic to mosquito larvae and inhibited the development of pupae. The high rates of larval mortality observed at higher concentrations (16 and $32 \mathrm{ppm}$ of the neem oil formulation) within $72 \mathrm{hrs}$ after exposure indicate the high toxicity of the product. The oil is also a potent insect growth regulator (IGR) which led to a $97.5 \%$ increase in larval development time and $97.1 \%$ decrease in pupation at $32 \mathrm{ppm}$ when compared to the corn oil and, as a result of the two, there was a 2.2 ( $8 \mathrm{ppm}$ ) to 44.5 $(32 \mathrm{ppm})$ decrease in the growth indices of the insects. These aspects, combined with the emergence inhibition activity ensure that the resultant mosquito population reduction is substantial, even where the larvicidal potential is minimal.

Table 2: Effects of neem oil and corn oil formulations on pupation, larval growth period and aquatic development rate of An. gambiae s.s.

\begin{tabular}{|c|c|c|c|c|c|c|}
\hline \multirow[b]{2}{*}{ Oil Concentration (ppm) } & \multicolumn{2}{|c|}{ \% Pupation } & \multicolumn{2}{|c|}{ Larval period (days) } & \multicolumn{2}{|c|}{ Growth indext } \\
\hline & Neem & Corn oil & Neem & Corn oil & Neem & Corn oil \\
\hline 32 & $1.00 \mathrm{cf}$ & $34.83 \mathrm{a}$ & $6.42 \mathrm{a}$ & $3.25 \mathrm{bc}$ & $0.48 \mathrm{~d}$ & $21.38 \mathrm{bc}$ \\
\hline 16 & $8.50 c$ & $38.67 \mathrm{a}$ & $5.72 \mathrm{ab}$ & $3.43 \mathrm{bc}$ & $3.58 \mathrm{~d}$ & $23.28 \mathrm{ab}$ \\
\hline 8 & $22.50 \mathrm{~b}$ & $44.67 \mathrm{a}$ & $4.62 \mathrm{abc}$ & $4.09 \mathrm{abc}$ & $10.22 \mathrm{~cd}$ & $22.33 \mathrm{ab}$ \\
\hline 4 & $35.00 \mathrm{a}$ & $40.50 \mathrm{a}$ & $2.87 \mathrm{c}$ & $3.58 b c$ & $26.84 a b$ & $23.87 \mathrm{ab}$ \\
\hline 2 & $37.00 \mathrm{a}$ & $43.00 \mathrm{a}$ & $4.05 \mathrm{abc}$ & $4.03 \mathrm{abc}$ & $19.24 \mathrm{bc}$ & $21.99 \mathrm{~b}$ \\
\hline 0.5 & $38.17 \mathrm{a}$ & $44.00 \mathrm{a}$ & $3.73 \mathrm{bc}$ & $3.70 \mathrm{bc}$ & $21.94 \mathrm{~b}$ & $23.80 \mathrm{ab}$ \\
\hline Control & \multicolumn{2}{|c|}{$44.50 \mathrm{a}$} & \multicolumn{2}{|c|}{$3.50 \mathrm{bc}$} & \multicolumn{2}{|c|}{$25.76 \mathrm{ab}$} \\
\hline
\end{tabular}

$\dagger \%$ pupation/mean larval period. $\ddagger$ Numbers in rows/columns without one or more letters in common are significantly different at $P<0.05$. Six concentrations were tested and replicated with 50 mosquitoes six times $(n=300)$ each. In some cases all larvae died $(32$ ppm of neem oil formulation), and it was assumed that at least one larva lived for at least as long as the experimental period ( 8 days) 
Table 3: Effect of sub-lethal concentrations of neem and corn oil formulations on mean $( \pm \mathrm{SD})$ and maximum (between brackets) adult An. gambiae s.s. longevity (in days).

\begin{tabular}{|c|c|c|c|c|c|c|c|c|}
\hline \multirow[t]{2}{*}{ Concentration (ppm) } & \multicolumn{2}{|c|}{8} & \multicolumn{2}{|c|}{4} & \multicolumn{2}{|c|}{2} & \multicolumn{2}{|c|}{ Control } \\
\hline & Male & Female & Male & Female & Male & Female & Male & Female \\
\hline Neemt & $\begin{array}{c}17.6 \pm 1.8 \\
(26)\end{array}$ & $\begin{array}{c}19.6 \pm 1.7 \\
(27)\end{array}$ & $\begin{array}{l}19.4 \pm 2.1 \\
(26)\end{array}$ & $\begin{array}{c}20.3 \pm 2.1 \\
(26)\end{array}$ & $\begin{array}{c}20.9 \pm 1.9 \\
(26)\end{array}$ & $\begin{array}{c}21.8 \pm 1.6 \\
(3 \mathrm{I})\end{array}$ & $\begin{array}{c}22.1 \pm 2.7 \\
(38)\end{array}$ & $\begin{array}{c}27.3 \pm 2.4 \\
\quad(42)\end{array}$ \\
\hline Corn & $\begin{array}{c}25.1 \pm 3.0 \\
(38)\end{array}$ & $\begin{array}{c}21.6 \pm 2.6 \\
(35)\end{array}$ & $\begin{array}{c}24.6 \pm 2.9 \\
(38)\end{array}$ & $\begin{array}{c}26.2 \pm 2.9 \\
\quad(3 I)\end{array}$ & $\begin{array}{c}21.2 \pm 2.7 \\
(38)\end{array}$ & $\begin{array}{c}29 \pm 1.9 \\
(33)\end{array}$ & & \\
\hline
\end{tabular}

† Third and fourth instar larval stages were treated.

As an emulsifiable concentrate, the neem oil formulation had greatly reduced-sized particles and was evenly mixed within the water column with a few suspended particles on the water surface. The spread of these fine particles probably increased the efficacy of the formulation since An. gambiae s.s. are small particle surface feeders. Larval feeding in this species also entails age-dependent and indiscriminate ingestion of any suitably sized particle [38], especially by the larger third and fourth instar larvae. When ingested, the neem product particles induce antifeedancy in larvae either by altering the insect's chemoreception or by reducing the food intake due to its toxicity [13]. Growth disruption was exhibited in both the pupae and the larvae. The percentage emergence in most cases was less than the percentage pupation, which suggests some pupal mortality, although this was not different from the control. The emergence inhibition (EI) values depicted with the neem oil formulation treatments were much lower than the respective lethal concentration (LC) values, an indication that the growth disruption activity of the neem product extended to pupal stages. This additional effect of neem oil ensures that it reduces the overall population of the insects beyond its larvicidal action.

The observation that the action of neem oil formulation was slow and that the neem oil formulation increased the mosquito larval periods was not unusual. Mortality of first instar culicids larvae collected after application of $30 \mathrm{mg} /$ L Margosan-O (an oil based neem seed extract) was 100\% after 15 days exposure in pool water [39]. Singh [35] found that a concentration of $32.1 \mathrm{ppm}$ of de-oiled neem seed kernel extract yielded $85 \%$ mortality in $C x$. quinquefaciatus after 12 days of exposure. Considering that our results were obtained by exposing mosquitoes as third and fourth instars, it is likely that treatment of younger instars would lower LC and EI values, thus providing even greater larvicidal potential. A number of studies have also elucidated this trend. For example Boschitz and Grunewald [25] studying Ae. aegypti showed age-dependent growth disruption; the sensitivity towards NeemAzal (a neem seed kernel powdered extract with 40\% azadirachtin content) decreased with increasing larval age.
The reduction in longevity of the emergent adults indicates that the neem oil formulation had sublethal effects carried over from the larval treatments. This observation is of significance with regard to the afrotropical malaria vector An. gambiae s.l., as a reduction in the average adult daily survival rate is key towards lowering its life-time transmission potential $[40,41]$.

Since the control formulation of corn oil had very minimal effects on the mosquitoes, it is certain that the effects described are due to the neem oil and not the emulsifier or solvent. The limited mortality exhibited by the corn oil formulation could have been caused by its oil effects. An important issue with regard to using neem-based products as larvicides is the rapid decay of its active ingredients such as azadirachtin when exposed to sunlight and $\mathrm{pH}$ changes $[11,13]$. Therefore, short term and repeated treatments may be necessary in field applications. This will increase application costs of larval control programmes, but will have the advantage of minimal residual activity and possible side effects.

A comparison of the results presented here with the outcome from various other studies on the efficacy of different neem products is difficult. There are numerous differences with the previous studies, notably because of differences in the origin of products, concentrations of active ingredients of the products, the species of mosquitoes tested, modes of application of the products, and parts of the neem plant from which the products were extracted. Besides this, the actual effective ingredient and its proportionate content are seldom mentioned in most studies. The results obtained in the various studies $[9,12,18,25,43,44]$ are shown in Table 4 . These show that various neem products have greatly varying azadirachtin contents, thereby making it impractical to calculate the product potencies with regard to percentages of azadirachtin. Nevertheless, these studies show dramatic impacts of neem formulations on hatch rates, larval development, and emergence inhibition, rendering neem a potentially useful addition to the arsenal of larval control substances.

Neem trees are found throughout Africa with a myriad of uses in medicine, pest control, reforestation etc. [42]. The 
Table 4: Comparison of the effects of various neem-based products and their azadirachtin contents on various mosquito species.

\begin{tabular}{|c|c|c|c|c|c|c|}
\hline Product description & Azadirachtin content & Mosquito species & Investigated effects & Recorded Potency & Larval Sages tested & Reference \\
\hline $\begin{array}{l}\text { Neem oil formulation, An } \\
\text { emulsified concentrate made } \\
\text { from neem seed oil extracts }\end{array}$ & $\begin{array}{l}0.03 \% \text { azadirachtin } \\
\text { content ( } 32 \% \text { neem oil) }\end{array}$ & An. gambiae & $\begin{array}{l}\text { Larval mortality, IGR } \\
\text { and inhibition of adult } \\
\text { emergence }\end{array}$ & $\begin{array}{l}\text { LC } 50 \text { of } 10.68 \mathrm{ppm} \text { and El } 50 \text { of } \\
6.44 \mathrm{ppm}\end{array}$ & $\begin{array}{l}3^{\text {rd }} \text { and } 4^{\text {th }} \text { instars } \\
\text { larvae and Adults }\end{array}$ & This article \\
\hline $\begin{array}{l}\text { Neem Azal (Neem seed kernel } \\
\text { powdered extract) }\end{array}$ & $\begin{array}{l}34 \% \text { Azadirachtin A and } \\
\text { a total limonoids } \\
\text { content of } 57.6 \%\end{array}$ & An. stephensi & $\begin{array}{l}\text { Effects of blood } \\
\text { feeding, oviposition, } \\
\text { and oocyst } \\
\text { ultrastructure }\end{array}$ & $\begin{array}{l}10-1000 \text { ppm treatments impair } \\
\text { feeding, oogenesis and } \\
\text { oviposition }\end{array}$ & Adults and oocyst & Lucantoni et al 2006 \\
\hline $\begin{array}{l}\text { Neem Azal (Neem seed kernel } \\
\text { powdered extract) }\end{array}$ & $\begin{array}{l}40 \% \text { Azadirachtin } \\
\text { content }\end{array}$ & Ae. aegypti & $\begin{array}{l}\text { Larval mortality, } \\
\text { molting inhibition }\end{array}$ & $\begin{array}{l}\text { Molting inhibition and larval } \\
\text { mortality occurred at all instars }\end{array}$ & $\begin{array}{l}2^{\text {nd }}, 3^{\text {rd }} \text { and } 4^{\text {th }} \text { instars } \\
\text { larvae }\end{array}$ & Boschitz. And Grunewald 1994 \\
\hline Emulsifiable concentrates & & Cx. tarsalis & Antifeedancy & $\begin{array}{l}5 \text { ppm- } 10 \text { ppm AZ induces } \\
\text { antifeedancy }\end{array}$ & Adults & Su and Mulla 1998 \\
\hline Neemix EC 4.5 & $0.0005 \%-0.001 \%$ & Cx. quinquefasciatus & & & & \\
\hline Azad EC 4.5 & 5 ppm-10 ppm & & & & & \\
\hline $\begin{array}{l}\text { Azad WP 10: wettable Product } \\
\text { Azad EC 4.5: Emulsifiable } \\
\text { concentrate }\end{array}$ & $0.001 \% 10 \mathrm{ppm}$ & Cx. tarsalis & Ovicidal & $\begin{array}{l}0 \% \text { hatching rate observed with } \\
\text { Azad WP } 10 \text { and } 46.7 \% \text { hatching } \\
\text { rate with Azad EC } 4.5\end{array}$ & Eggs & Su and Mulla 1998 \\
\hline $\begin{array}{l}\text { Water based pure neem oil } \\
\text { emulsion }\end{array}$ & Not indicated & $\begin{array}{l}\text { An. stephensi } C x \text {. } \\
\text { quinquefasciatus }\end{array}$ & $\begin{array}{l}\text { Inhibition of Adult } \\
\text { emergence }\end{array}$ & $\begin{array}{l}0.1 \mathrm{ml} / / \text { of } 5 \% \text { of the neem oil } \\
\text { caused } 100 \% \text { emergence } \\
\text { inhibition }\end{array}$ & $\begin{array}{l}\text { Imatures (aquatic } \\
\text { stages) }\end{array}$ & Batra et al 1998 \\
\hline $\begin{array}{l}\text { Water based pure neem oil } \\
\text { emulsion }\end{array}$ & Not indicated & Ae. aegypti & $\begin{array}{l}\text { Inhibition of Adult } \\
\text { emergence }\end{array}$ & $\begin{array}{l}0.4 \mathrm{ml} / / \mathrm{l} \text { of } 5 \% \text { of the neem oil } \\
\text { caused } 100 \% \text { emergence } \\
\text { inhibition }\end{array}$ & $\begin{array}{l}\text { Imatures (aquatic } \\
\text { stages) }\end{array}$ & Batra et al 1998 \\
\hline $\begin{array}{l}\text { Pure neem oil made from seed } \\
\text { extracts }\end{array}$ & Not indicated & $\begin{array}{l}\text { Cx. quinquefasciatus Ae. } \\
\text { aegypti }\end{array}$ & Larval mortality & $\begin{array}{l}0.02-0.1 \% \text { caused } 100 \% \text { larval } \\
\text { mortality }\end{array}$ & $4^{\text {th }}$ instar larvae & Sinniah et al 1994 \\
\hline $\begin{array}{l}\text { Neem formulation (name in } \\
\text { the original paper is in Arabic) }\end{array}$ & $\begin{array}{l}0.6 \mathrm{ppm}-1.9 \mathrm{pm} \\
0.00006 \%-0.00019 \%\end{array}$ & $\begin{array}{l}\text { Ochlerotatus japonicus } C x . \\
\text { pipiens pallens }\end{array}$ & $\begin{array}{l}\text { Larval mortality and } \\
\text { inhibition of adult } \\
\text { emergence. }\end{array}$ & $\begin{array}{l}\text { LC50 of } 0.342 \text { and } 0.367 \text { for } \\
\text { Ochlerotatus japonicus and Culex } \\
\text { pipiens pallens respectively. } 1.9 \\
\text { Ppm and } 0.6 \text { ppm solutions } \\
\text { caused } 99 \% \text { and } 75 \% \text { emergence } \\
\text { inhibition respectively }\end{array}$ & $4^{\text {th }}$ Instar Larvae & Mikami and Yamashita 2004 \\
\hline
\end{tabular}


oil can be obtained through pressing (crushing) of the seed kernel both through cold pressing or through a process incorporating temperature controls. The oil yield varies from $25-45 \%$ [42]. Its use as a mosquito larvicide will require addition of a surfactant and solvent to ensure equal distribution over water surfaces. Initial experimentation with a neem formulation applied from a knapsack sprayer demonstrated the relative ease with which larval control can take place. Manufacturing of these larvicides can be stimulated through local businesses and does not, unlike current larvicides such as Bti or temephos, require importation from outside Africa. With more decentralized and community-based vector control initiatives underway in Africa $[45,46]$ neem-based larvicides may present an ideal option to increase these efforts.

\section{Conclusion}

The neem oil formulation is a highly effective larvicide for anopheline mosquito vector control. Field application for this product may include high pressure knapsack or ultralow volume (ULV) sprayers ensuring even application. Further studies are necessary to evaluate the optimum dosages for efficient mosquito control under natural field conditions. Non-target effects on other water inhabiting insects, especially mosquito larvae predators also need further investigation.

\section{Competing interests}

The author(s) declare that they have no competing interests.

\section{Authors' contributions}

FO conducted the experiments and drafted the manuscript. UF and BK supervised the experimental work and participated in the writing of the final versions of the manuscript. UF also oversaw the acquisition of laboratory requirements and provision of literature and other logistical issues towards the publication of the article.

\section{Acknowledgements}

The International Center of Insect Physiology and Ecology (ICIPE) is acknowledged for providing essential laboratory and green house facilities. We thank Prof. Steve Lindsay and Dr. Sarah Moore for commenting on earlier versions of the manuscript. Our appreciation goes to the Ifakara Health Research and Development Centre, Tanzania, for logistical and financial support during the final stages of the manuscript development. The work was funded through sponsorship from a private donor from the USA and a VIDI grant (no. 864.03.004) awarded by the Dutch Scientific Organization (NWO) to BGJK.

\section{References}

I. Gratz NG, Pal R: Malaria vector control: larviciding. In Malaria: Principles and Practices of Malariology Edited by: Wernsdorfer WH, McGregor I. London: Churchill Livingstone; 1989:1213-1226.

2. Bockarie MJ, Gbakima AA, Barnish G: It all began with Ronald Ross: 100 years of malaria research and control in Sierra Leone (1899-1999). Ann Trop Med Parasitol 1999, 93:2 I3-224.
3. Killeen GF, Fillinger $U$, Knols BG]: Advantages of larval control for African malaria vectors: low mobility and behavioural responsiveness of immature mosquito stages allow high effective coverage. Malar J 2002, I:8.

4. Soper FL, Wilson DB: Anopheles gambie in Brazil. New York: Rockeffeller Foundation; 1943.

5. Shousha AT: Species-eradication: the eradication of Anopheles gambiae from Upper Egypt 1942-1945. Bull World Health Org 1948, I:309-353.

6. Fillinger $U$, Knols BG], Becker $\mathrm{N}$ : Efficacy and efficiency of a new Bacillus thuringiensis var. israelensis and Bacillus sphaericus formulations against Afrotropical anophelines in Western Kenya. Trop Med Int Health 2003, 8:37-47.

7. Shililu JI, Tewolde GM, Brantly E, Githure JI, Mbogo CM, Beier JC, Fusco R, Novak RJ: Efficacy of Bacillus thuringiensis israelensis, Bacillus sphaericus and temephos for managing Anopheles larvae in Eritrea. J Am Mosq Control Assoc 2003, 19:251-258.

8. Kamsuk K, Choochote W, Chaithong U, Jitpakdi A, Tippawangkosol $P$, Riyong D, Pitasawat B: Effectiveness of Zanthoxylum piperitum - derived essential oil as an alternative repellent under laboratory and field application. Parasitol Res 2007, 100:339-345.

9. Lucantoni L, Giusti F, Cristofaro M, Pasqualini L, Esposito F, Lupetti P, Habluetzel A: Effects of neem extract on blood feeding, oviposition and oocyte ultrastructure in Anopheles stephensi Liston (Diptera: Culicidae). Tissue Cell 2006, 38:36I-37I.

10. Isman MB: Botanical insecticides, detterents and repellents in modern agriculture and an increasingly regulated world. Annu Rev Entomol 2006, 51:45-66.

II. Schmutterer H, editor: The Neem Tree (Azadirachtaindica A Juss) and other Meliaceous Plants: Sources of Unique Natural Products for Integrated Pest Management, Medicine, Industry and other Purposes. Ist edition. Mumbai: Neem Foundation; 2002.

12. Su T, Mulla MS: Antifeedancy of neem products containingAzadirachtin against Culex tarsalis and Culex quinquefasciatus (Diptera: Culicidae). J Vector Ecol 1998, 23: I I4-I22.

13. Mordue (Luntz) AJ, Blackwell A: Azadirachtin: an Update. J Insect Physiol 1993, 39:903-924.

14. Mordue (Luntz) AJ, Nisbet AJ: Azadirachtin from the neem tree Azadirachta indica: its actions against insects. Ann Entomol Soc Brasil 2000, 29:615-632.

15. Singh N, Mishra AK, Saxena A: Use of neem cream as a mosquito repellent in tribal areas of central India. Indian J Malariol 1996, 33:99-102.

16. Sharma VP, Ansari MA, Razdan RK: Mosquito repellent action of neem (Azadirachta indica) oil. J Am Mosq Control Assoc 1993, 9:359-360.

17. Sharma VP, Dhiman RC: Neem oil as a sand fly (Diptera: Psychodidae) repellent. J Am Mosq Control Assoc 1993, 9:364-366.

18. Su T, Mulla MS: Ovicidal activity of neem products (azadirachtin) against Culex tarsalis and Culex quinquefasciatus (Diptera: Culicidae). J Am Mosq Control Assoc 1998, 14:204-209.

19. Kreutzweiser DP: Non-target effects of neem based insecticides on aquatic invertabrates. Ecotoxicol Env Safety 1997, 36:109-117.

20. Stark JD: Population level effects of neem insecticide, Neemix on Daphnia pulex. J Env Sci Hlth B 200I, 36:457-465.

21. Goektepe I, Portier R, Ahmedna M: Ecological risk assessment of neem based pesticides. J Env Sci Hlth B 2004, 39(2):3 I I-320.

22. Mulla MS, Su T: Activity and biological effects of neem products against arthropods of medical and veterinary importance. J Am Mosq Control Assoc 1999, I5(2): I33-152.

23. Sagar SK, Sehgal SS: Effects of aqueous extract of deoiled neem (Azadirachta Indica A. juss) seed kernel and karanja (Pongamia Glabra vent) seed kernel against Culex quinquefasciatus. J Commun Dis 1996, 28:260-269.

24. Monzon RB, Alvior JP, Luczon LL, Morales AS, Mutuc FE: Larvicidal potential of five Philippine plants against Aedes aegypti (Linnaeus) and Culex quinquefasciatus (Say). Southeast Asian J Trop Med Public Health 1994, 25:755-759.

25. Boschitz C, Grunewald J: The effect of NeemAzal on Aedes aegypti (Diptera: Culicidae). Appl Parasitol 1994, 35:25 I-256.

26. el-Shazly MM, el-Sharnoubi ED: Toxicity of a neem (Azadirachta indica) insecticide to certain aquatic organisms. J Egypt Soc Parasitol 2000, 30:22I-231. 
27. Ziba MM: Preliminary laboratory trial of Neem on Anopheles and culex larvae in Zambia. Cent Afr J Med 1995, 41:137-138.

28. Nathan SS, Kalaivani K, Murugan K: Effects of neem limonoids on the malaria vector, Anopheles stephensi Liston (Diptera: Culicidae). Acta Trop 2005, 96:47-55.

29. World Health Organization: Manual on practical entomology in Malaria part 2: methods and techniques. Geneva: World health Organization; 1975.

30. Animal Rearing and Quarantine Unit: Standard Operating Procedures. Nairobi: International Centre of Insect Physiology and Ecology, ICIPE; 1999.

31. Amstrong JA, Bransby-Williams WR: Maintainance of a colony of Anopheles gambiae with observations on the effects of changes in temperature. Bull World Health Org 1961, 24:42-437.

32. Knols BG], Njiru BN, Mathenge EM, Mukabana WR, Beier JC, Killeen GF: MalariaSphere: A greenhouse-enclosed simulation of a natural Anopheles gambiae (Diptera: Culicidae) ecosystem in western Kenya. Malar J 2002, I:19.

33. World Health Organization: Instructions for determining the susceptibility or resistance of mosquito larvae to insecticides. Geneva: WHO; 198I.

34. Scott IM, Kaushik NK: The toxicity of a neem insecticide to populations of culicidae and other aquatic invertebrates as assessed in in situ microcosms. Arch Environ Contam Toxicol 2000, 39:329-336.

35. Singh RP: Effects of water extract of deoiled neem kernel on second instar larvae of Culex fatigans Wiedemann. Neem Newsletter 1984, I:16.

36. Abbott WS: A method for computing the effectiveness of an insecticide. J Econ Entomol 1925, 18(2):265-267.

37. Finney DJ: Probit Analysis (Third Edition). 3rd edition. Cambridge University Press, UK; 1971.

38. Kettle DS: Medical and Veterinary Entomology. 2nd edition. Oxford: Oxford University Press; 1995

39. Scott IM, Kaushik NK: The toxicity of margosan-O, a product of neem seeds, to selected target and nontarget aquatic invertebrates. Arch Environ Contam Toxicol 1998, 35:426-431.

40. MacDonald G: The epidemiology and control of malaria. London: Oxford University Press; 1957.

41. Scholte EJ, Ng'habi K, Kihonda J, Takken W, Paaijmans K, Abdulla S, Killeen GF, Knols BGJ: An entomopathogenic fungus for control of adult African malaria mosquitoes. Science 2005 308: $|64|-1642$.

42. Vietmeyer N, (Ed): Neem: A tree for solving global problems. The National Academies Press; 1992.

43. Sinniah B, Sinniah D, Ibrahim J: Effect of neem oil on mosquito larvae. Mosq Borne Dis Bull 1994, I:90-93.

44. Mikami A, Yamashita N: Inhibitory effects of neem formulation on emergence of Ochlerotatus japonicus and Culex pipiens pallens. Med Entomol Zool 2004, 55:239-242.

45. Mukabana WR, Kannady K, Kiama GM, ljumba JN, Mathenge EM, Kiche I, Nkwengulila G, Mboera L, Mtasiwa D, Yamagata Y, van Schayk I, Knols BG], Lindsay SW, Caldas de Castro M, Mshinda H, Tanner M, Fillinger U, Killeen GF: Ecologists can enable communities to implement malaria vector control in Africa. Malar J 2006, 5:9.

46. Van den Berg H, Knols BG]: The Farmer Field School: A method for enhancing the role of rural communities in malaria control? Malar J 2006, 5:3.
Publish with Bio Med Central and every scientist can read your work free of charge

"BioMed Central will be the most significant development for disseminating the results of biomedical research in our lifetime. "

Sir Paul Nurse, Cancer Research UK

Your research papers will be:

- available free of charge to the entire biomedical community

- peer reviewed and published immediately upon acceptance

- cited in PubMed and archived on PubMed Central

- yours - you keep the copyright
BioMedcentral 